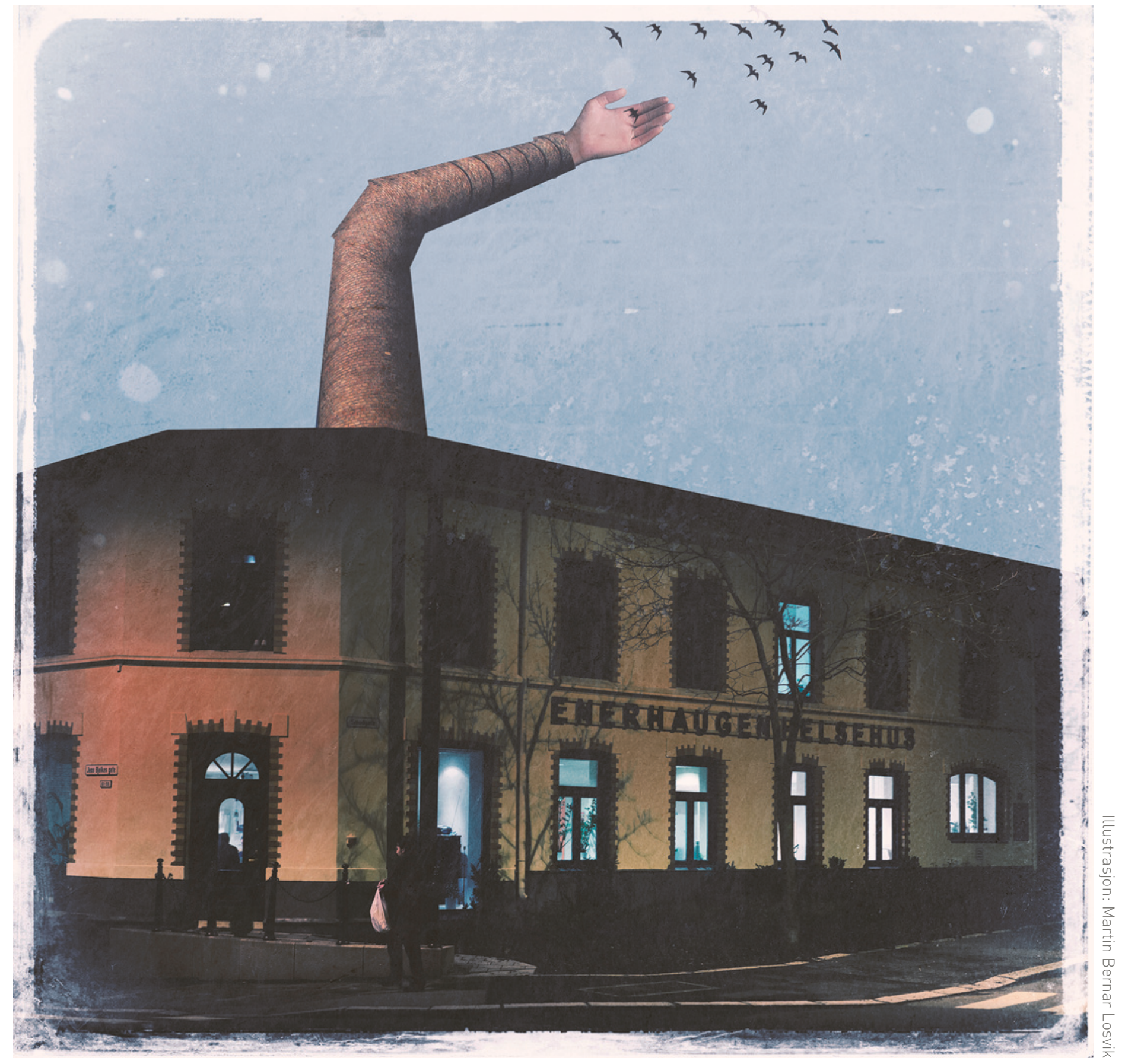

\title{
Enerhaugen Legesenter
}

(i)

Enerhaugen Legesenter ligger på Tøyen, som er det tettest befolkede området i Oslo.

Senteret åpnet vinteren 2014 og har seks ansatte - fire leger og to helsesekretærer. 